\title{
AKTIVITAS DARI INDUSTRI RUMAH PANGGUNG DI DESA TOMBASIAN ATAS KECAMATAN KAWANGKOAN BARAT
}

\author{
Claudio Biorhof Ering \\ Caroline Betsi Diana Pakasi \\ Ellen Grace Tangkere
}

\begin{tabular}{ll}
\hline Naskah diterima melalui Website Jurnal Ilmiah agrisosioekonomi@unsrat.ac.id & : Rabu, 09 Oktober 2019 \\
Disetujuiditerbitkan & : Selasa, 22 Oktober 2019 \\
\hline
\end{tabular}

\begin{abstract}
The purpose of this research is to analyze the activities of the stilt house industry. The sampling method in this study uses a purposive sampling method with a total sample of 15 respondents from a population of 36 owners of stilt house industries in the Upper Tombasian Village. The research results show that the activities of the stage house industry in the Upper Tombasian Village include production activities, namely the preparation of raw materials, the design process, ordering, and distribution. Production activities from the stilt house industry provide income where labor is absorbed from within the village itself, depend on number of rooms each house. Thet are 1 room (6 x 5) absorbs 3 workers, 2 rooms ( $7 \times$ 9) absorb 4 workers, 3 rooms $(7 \times 12)$ absorb 5 workers. Income for owners where the owner owns a stilt house business, income for the village through tax collection for every 1 unit of house sold. Income for the surrounding community in the form of renting a vehicle for the distribution process is Rp. 600,000 - Rp. 1,200,000, depending on distance traveled. ${ }^{* e p r m *}$
\end{abstract}

Keywords: activity, industry, houses on stilts, Upper Tombasian Village, West Kawangkoan District

\begin{abstract}
ABSTRAK
Tujuan penelitan ini adalah untuk menganalisis aktivitas dari industri rumah panggung di Desa Tombasian Atas Kecamatan Kawangkoan Barat. Metode pengambilan sampel dalam penelitian ini menggunakan metode pemilihan sampel secara sengaja (purposive sampling) dengan jumlah sampel sebanyak 15 responden dari populasi 36 pemilik industri rumah panggung yang ada di Desa Tombasian Atas. Hasil penelitihan menunjukkan bahwa aktivitas dari industri rumah panggung di Desa Tombasian Atas meliputi aktivitas produksi yaitu persiapan bahan baku, proses desain, pemesanan, dan distribusi. Aktivitas produksi dari industri rumah panggung memberikan pedapatan dimana terjadi penyerapan tenaga kerja dari dalam desa sendiri, yaitu 1 kamar $(6 \times 5)$ menyerap 3 tenaga kerja, 2 kamar $(7 \times 9)$ menyerap 4 tenaga kerja, 3 kamar $(7 \times 12)$ menyerap 5 tenaga kerja. Pendapatan bagi pemilik dimana pemilik yang memiliki usaha rumah panggung, Pendapatan bagi desa melalui pemungutan pajak untuk setiap 1 unit rumah yang terjual. Pendapatan bagi masyarakat sekitar dalam bentuk menyewa kendaraan untuk proses distribusi Rp 600.000, - Rp 1.200.000, tergantung jarak tempuh. ${ }^{*}$ prm*
\end{abstract}

Kata kunci : aktivitas, industri, rumah panggung, Desa Tombasian Atas, Kecamatan Kawangkoan Barat 


\section{PENDAHULUAN}

\section{Latar Belakang}

Aktivitas adalah suatu kegiatan yang dapat di jumpai dalam proses administrasi. Hal ini sejalan dengan pengertian yang dikemukakan oleh Tjokroamidjojo (1990) sebagai berikut : Aktivitas adalah usaha-usaha yang dikemukakan untuk melaksanakan semua rencana dan kebijaksanaan yang telah dirumuskan dan ditetapkan untuk melengkapi segala kebutuhan alat-alat yang diperlukan, siapa yang akan melaksanakan, ditempat mana pelaksanaannya, kapan waktu dimulai dan berakhir, dan bagaimana cara yang harus dilakukan. Pengertian lain menurut Tjokroamudjojo, Aktivitas sebagai proses dapat dipahami dalam bentuk rangkaian kegiatan yakni berawal dari kebijaksanaan itu diturunkan dalam bentuk proyek.

Dengan demikian dalam operasionalnya, aktivitas dapat dirasakan perlu adanya penerapan dan fungsi manajemen yakni pelaksanaan kegiatan opersional. Dengan dasar pemahaman bahwa rangkaian tidak lanjut merupakan upaya positif (efektif dan efisien) kearah tujuan akhir. Disamping itu adanya pergerakan kegiatan dalam suatu tujuan tertentu.

Industri berperan strategis untuk mendukung pertumbuhan ekonomi yang cukup tinggi secara berkelanjutan dan meningkatkan produktivitas masyarakat. Industri juga berperan menciptakan lapangan usaha serta memperluas kesempatan kerja, meningkatkan serta menghemat devisa, mendorong pembangunan daerah, meningkatkan serta memeratakan pendapatan masyarakat dan mengentaskan kemiskinan. Proses industrialisasi dalam pembangunan industri juga penting dalam mendukung berlangsungnya perubahan tata nilai masyarakat dan pranata sosial yang lebih dinamis dan berkualitas.

Keberadaan industri pada setiap daerah akan membawa perubahan terhadap kehidupan masyarakat sekitarnya. Diantaranya terjadi peningkatan kegiatan sosial maupun kegiatan ekonomi industri. Industri rumah panggung merupakan salah satu dilakukan masyarakat minahasa seperti yang di lakukan oleh masyarakat di Desa Mokobang Kabupaten Minahasa Selatan, di Desa Woloan Kota Tomohon dan di Desa Tombasian Atas Kecamatan Kawangkoan Barat.

\section{Pendapatan}

Menurut Pelle C. M. (2012), pendapatan merupakan hasil pengurangan antara jumlah penerimaan dengan biaya yang di keluarkan, semakin besar produksi yang dipasarkan semakin besar pula pendapatan yang diperoleh, besarnya jumlah pendapatan mempunyai fungsi untuk pemenuhan kebutuhan hidup sehari-hari, apabila pendapatan meningkat maka sebagian pendapatan akan disimpan dalam bentuk tabungan.

Pendapatan dapat juga diuraikan sebagai keseluruhan penerimaan yang di terima pekerja, buruh atau rumah tangga, baik berupa fisik maupun non-fisik bekerja atau berusaha, Nababan (2009).

\section{Upah}

Upah atau imbalan yang diberikan oleh pengusaha terhadap pekerja untuk satu pekerja untuk suatu pekerja atau jasa yang telah dilakukan atau akan dilakukan, dinilai dalam bentuk ruang yang di tetapkan dalam suatu persetujuan. Dalam undang-undang Nomor 3 tahun 1992 tentang jaminan sosial tenaga kerja dielaskan bawah upah adalah penerimaan sebagai imbalan dari pengusaha kepada tenaga kerja untuk suatu pekerjaan yang telah atau akan dilakukan.

Menurut Alam S. (2006) Penghitungan upah:

1) Upah menurut waktu, setiap tenaga kerja dibayar dalam satuan waktu. Misalnya sekian rupiah per bulan, per hari atau per jam.

2) Upah satuan pada sistem ini tenaga kerja dibayar berdasarkan jumlah satuan unit produksi yang dapat diselesaikannya. Makin banyak satuan unit produksi yang dikerjakan, makin banyak upah yang terima.

3) Upah borongan, ialah upah yang dibayarkan berdasarkan suatu unit pekerjaan secara keseluruhan. Pekerjaan yang menggunakan sistem upah borongan biasanya adalah pekerjaan yang berkaitan dengan proyekproyek tertentu seperti proyek pembangunan.

\section{Rumusan Masalah}

Rumusan masalah dalam penelitian ini adalah bagaimana Aktivitas Dari Industri Rumah Panggung di Desa Tombasian Atas Kecamatan Kawangkoan Barat. 


\section{Tujuan}

Tujuan penelitian ini adalah untuk menganalisis Aktivitas Dari Industri Rumah Panggung di Desa Tombasian Atas Kecamatan Kawangkoan Barat.

\section{Manfaat Penelitian}

Penelitian ini bermanfaat untuk :

1. Menjadi sumber informasi bagi pemerintah setempat untuk mengetahui bagaimana Aktivitas Dari Rumah Panggung di Desa Tombasian Atas Kecamatan Kawangkoan Barat.

2. Bagi peneliti sebagai salah satu cara untuk mengetahui Aktivitas Dari Rumah Panggung di Desa Tombasian Atas, Kecamatan Kawangkoan Barat.

3. Bagi mahasiswa atau yang memerlukan, dapat dijadikan referensi kajian dalam bidang serupa.

\section{METODE PENELITIAN}

\section{Jenis Data dan Sumber Data}

Data yang digunakan dalam penelitian ini adalah data primer yang di kumpulkan melalui wawancara langsung dengan pemilik industri rumah panggung di Desa Tombasian Atas Kecamatan Kawangkoan Barat dan data sekunder dari Kantor Desa Tombasian Atas Kecamatan Kawangkoan Barat yang berkaitan dengan penelitian. Metode pengumpulan data dilakukan dengan cara pemberian angket (Questionnaire) yang berasal dari objek yang dileliti yaitu pemilik industri rumah panggung di desa Tombasian Atas, Kecamatan Kawangkoan Barat. Untuk diisi kemudian lembar kuisioner dikumpulkan, diolah dan kemudian dianalis is.

\section{Konsep Pengukuran Variabel}

1. Karakteristik Responden Pemilik Usaha Meliputi
a. Umur Responden (tahun)
b. Tingkat Pendidikan Responden (pendidikan terakhir responden)
c. Pekerjaan Responden
d. Jenis Kelamin (laki-laki/perempuan)

Untuk mengetahui bagaimana Aktivitas Industri Rumah Panggung, adapun variabel yang diukur sebagai berikut:

2. Aktivitas Produksi Industri Rumah Panggung

a. Persiapan Bahan Baku

Yaitu aktivitas yang perlu dipersiapkan sebelum memulaikan proses pembuatan rumah panggung, dalam menyiapkan bahan baku beberapa hal yang diperhatikan :

1) Jenis Bahan Baku

2) Sumber Bahan Baku

3) Harga Bahan Baku

b. Pemesanan

Yaitu aktivitas yang terjadi ketika rumah panggung sebelum diproduksi, dimana ada proses konsumen memesan rumah panggung sesuai kebutuhan, pada proses pemesanan terjadi proses penentuan harga.

c. Membuat Desain

Yaitu aktivitas yang terjadi jika ada permintaan desain khusus dari konsumen.

d. Proses Produksi

Yaitu aktivitas dimana rumah panggung akan dibuat baik sesuai pemesanan atau permintaan desain, maupun yang akan dipajang. Dalam proses produksi, terjadi proses :

1) Persiapan

2) Pembuatan

3) Penyelesaian (finishing)

e. Pemasaran

Yaitu aktivitas yang terjadi setelah rumah panggung selesai diprosuksi.

f. Distribusi

Yaitu aktivitas dimana rumah panggung sudah laku terjual, dan siap diantar kepada pembeli.

3. Aktivitas dari Industri Rumah Panggung
a. Penyerapan tenaga kerja
b. Upah tenaga kerja (Rp)
c. Pendapatan Industri Rumah Panggung (Rp)

\section{Analisis Data}

Metode Analisis data dalam penelitian ini menggunakan analisis deskriptif yaitu menjelaskan data-data dalam tabel kemudian dijelaskan dengan kat-kata. 


\section{HASIL DAN PEMBAHASAN}

\section{Gambaran Umum Wilayah Penelitian Sejarah Desa}

Desa Tombasian Atas atau "Tou In

Wasian" yang merupakan legenda Minahasa, kononnya tempat dahulu kala tumbuh pohon sangat besar yang bernama wasian, pohon wasian ini sebesar lapangan sepak bola. Tombasian Atas adalah Desa di Kecamatan Kawangkoan Barat, Kabupaten Minahasa, yang sebagian besar penduduk Desa Tombasian Atas memiliki keahlian dalam pengolahan nira aren menjadi alkohol berkualitas tinggi (cap tikus) yang mempunyai kadar alkohol hingga $80 \%$.

Selain itu masyarakat Desa Tombasian Atas mengembangkan keterampilan mereka dalam bidang konstruksi bangunan rumah kayu (rumah panggung) yang saat ini pemasaran penjualannya telah sampai keluar daerah. Desa Tombasian Atas memanfaatkan air tanah dari pegunungan Rindengan yang murni sebagai kebutuhan sehari-hari. Bahkan saat ini telah ada anggota masyarakat yang telah memanfaatkannya sebagai sumber penghasilan di bidang pengisian ulang air minum.

\section{Letak Wilayah}

Desa Tombasian Atas adalah sebuah Desa yang terletak diwilayah Kecamatan Kawangkoan Barat, Kabupaten Minahasa, Provinsi Sulawesi Utara. Terdiri Dari 5 jaga/dusun yaitu Jaga I, Jaga II, Jaga III, Jaga $\mathrm{IV}$, dan Jaga $\mathrm{V}$ dengan batas wilayah yaitu:

- Sebelah Utara : Desa Tombasian Atas Satu

- Sebelah Timur : Desa Kanonang Satu

- Sebelah Selatan: Pegunungan Rindengan

- Sebealah Barat : Desa Tombasian Bawah

\section{Karakteristik Responden Pemilik Usaha Umur Responden}

Tingkat umur merupakan salah satu faktor yang mempengaruhi kemampuan seseorang dalam melakukan aktivitas maupun konsep berpikir. Responden yang berumur muda tentunya memiliki kondisi fisik lebih kuat dibandingkan dengan responden yang berumur tua. Secara umum dapat dikatakan bahwa makin tinggi umur maka makin berkurang kemampuan berprestasi sebagai tenaga kerja. Umur responden dalam penelitian ini disajikan pada Tabel 1 .
Tabel 1. Jumlah Responden menurut Umur

\begin{tabular}{lccc}
\hline No. & Umur (Tahun) & $\begin{array}{c}\text { Jumlah Responden } \\
\text { (orang) }\end{array}$ & Persentase(\%) \\
\hline 1. & $30-40$ & 6 & 40 \\
2. & $41-50$ & 6 & 40 \\
3. & $51-60$ & 3 & 20 \\
\hline Jumlah & 15 & 100 \\
\hline
\end{tabular}

Sumber : Data Primer, diolah 2019

Tabel 1 menunjukkan bahwa responden pada interval umur 30-40 tahun sama banyak dengan responden interval umur 41-50 tahun dengan persentase sebesar $40 \%$, sedangkan respondengan dengan interval umur 51-60 tahun hanya sebesar $20 \%$.

\section{Pendidikan Responden Pemilik}

Perkembangan suatu usaha dalam bidang apapun haruslah ditunjang oleh faktor pendidikan baik formal maupun non formal. Tingkat pendidikan responden pemilik dapat dilihat pada Tabel 2.

Tabel 2. Tingkat Pendidikan Responden

\begin{tabular}{|c|c|c|c|}
\hline No. & $\begin{array}{c}\text { Tingkat } \\
\text { Pendidikan }\end{array}$ & $\begin{array}{c}\text { Jumlah } \\
\text { Responden } \\
\text { (orang) }\end{array}$ & Persentase $(\%)$ \\
\hline 1 . & $\begin{array}{c}\text { Tidak } \\
\text { Bersekolah }\end{array}$ & - & - \\
\hline 2. & SMP & 1 & 6 \\
\hline 3. & SMA & 10 & 67 \\
\hline 4. & $\begin{array}{l}\text { Perguruan } \\
\text { Tinggi }\end{array}$ & 4 & 27 \\
\hline & Jumlah & 15 & 100 \\
\hline
\end{tabular}

Sumber : Data Primer, diolah 2019

Tabel 2 menunjukkan bahwa tingkat pendidikan yang dimiliki responden yang paling banyak yaitu tingkat SMA sebanyak $67 \%$ responden, tingkat perguruan tinggi sebanyak $27 \%$, tingkat SMP sebanyak $6 \%$ responden.

\section{Pekerjaan Responden Pemilik}

Tabel 3 menujukkan pekerjaan tetap dari responden, sehingga industri rumah panggung menjadi usaha sampingan bagi responden, dari 6 kategori jenis pekerjaan dari responden pemilik, yaitu PNS, tukang, mengurus rumah tangga, pegawai swasta, petani, Aparat. Kategori tukang kayu dan petani merupakan jenis pekerjaan terbanyak dari responden pemilik yaitu dengan persentense sebesar 33\%, jenis pekerjaan pegawai negeri sipil dengan persentense sebanyak 3 orang $20 \%$, jenis pekerjaan mengurus rumah tangga $14 \%$, dan Aparat 2 orang presentase sebesar 13\%, dan sedangkan jenis pekerjaan yang paling sedikit yaitu pegawai swasta dengan persentense sebesar $6 \%$. 
Tabel 3. Jumlah Responden yang memiliki pekerjaan

\begin{tabular}{clcc}
\hline No. & Jenis Pekerjaan & $\begin{array}{c}\text { Jumlah } \\
\text { Responden } \\
\text { (orang) }\end{array}$ & Persentase(\%) \\
\hline 1. & Pegawai Negeri & 3 & 20 \\
& Sipil & 2 & 14 \\
2. & Tukang & 2 & 14 \\
3. & Mengurus & & \\
& rumah & 1 & 6 \\
4. & tangga & 5 & 33 \\
5. & Pegawai Swasta & 2 & 13 \\
6. & Aparat & 15 & 100 \\
\hline & Jumlah &
\end{tabular}

Sumber : Data Primer, diolah 2019.

\section{Jenis Kelamin}

Berdasarkan jenis kelamin pemilik usaha industri rumah panggung di Desa Tombasian Atas Kecamatan Kawangkoan Barat, dapat dilihat pada Tabel 4.

Tabel 4. Jumlah Responden menurut jenis kelamin

\begin{tabular}{lccc}
\hline No. & $\begin{array}{c}\text { Jenis } \\
\text { Pekerjaan }\end{array}$ & $\begin{array}{c}\text { Jumlah } \\
\text { Responden } \\
\text { (orang) }\end{array}$ & Persentase(\%) \\
\hline 1. & Laki-laki & 11 & 73 \\
2. & Perempuan & 4 & 27 \\
\hline & Jumlah & 15 & 100 \\
\hline
\end{tabular}

Sumber : Data Primer diolah, 2019.

Tabel 4 menunjukkan bahwa jumlah responden jenis kelamin laki-laki lebih lebih banyak dengan persentase $73 \%$ dari responden pemilik dan jumlah responden perempuan lebih sedikit dengan persentase $27 \%$ responden pemilik.

\section{Aktivitas Produksi Industri Rumah Panggung}

Industri Rumah Panggung yang ada di

Desa Tombasian Atas sendiri masih merupakan Industri yang dikelolah oleh rumah tangga, dalam arti lain belum ada Perusahan atau CV yang kelolah. Akivitas Industri Rumah panggung dapat kita lihat pada uraian berikut ini.

\section{Persiapan Bahan Baku}

Bahan baku merupakan salah satu unsur yang paling penting didalam perusahan yang secara terus menerus di peroleh, diolah (input) yang kemudian dijual (output) kembali. Bahan baku merupakan barang-barang yang diperoleh untuk digunakan dalam proses produksi. Beberapa bahan baku diperoleh secara langsung dari sumber daya alam yang ada didaerah.

\section{Jenis Bahan Baku}

Setiap tukang tahu untuk memilih kayu dalam memilih kayu yang terbaik dalam mendirikan rumah panggung. Sehingga kayu yang digunakan adalah kayu yang berkualitas dan yang terbaik berdampak baik bagi kualitas dari rumah panggung. Dari hasil wawancara 15 responden pemilik usaha rumah panggung keseluruhanya mengatakan untuk kayu yang di gunakan dalam usaha rumah panggung di Desa Tombasian Atas keseluruhannya seperti pintu, konseng, jendela, plavon dll menggunakan kayu cemapaka karena selain kualitasnya bagus kayu cempaka merupakan kayu yang selalu digunakan dalam industri rumah panggung.

Bahan baku selanjutnya yaitu Seng yang merupakan atap dari rumah panggung dan jenis seng yang digunakan yaitu Cap Gajah karena seng gelombang cap gajah ini lebih cocok pada industri rumah panggung dibandingkan dengan seng-seng lainnya. Kemudian bahan baku selanjutnya yaitu paku, jenis paku yang digunakan yaitu paku yang berukuran 1 inch, 1,5 inch, 2 inch, 2,5 inch dan 4 inch.

Jenis bahan baku selanjutnya yaitu batu teras dan semen yang digunakan untuk dasar Rumah Panggung. Fungsi dari batu teras dan semen agar tiang pada rumah panggung tidak tersentuh langsung dengan dasar tanah. Jenis semen yang digunakan yaitu semen tiga roda. Bahan baku lainnya itu engsel pintu, engsel jedela, grendel jendela, kaca jendela, tarikan jendela, baut dan dan kunci pintu.

\section{Sumber Bahan Baku}

Desa Tombasian Atas merupakan desa yang dikenal dengan tumbuhan dan tanaman yang subur, karena Desa Tombasian Atas berada pada tingkat ketinggian yang jauh dari permukaan laut. Dalam hal ini dari 15 responden pemilik usaha Rumah Panggung setelah diwawancarai, 10 responden mengatakan dalam mendapatkan sumber bahan baku dasar (kayu) untuk rumah panggung bisa didapat di dalam Desa Tombasian Atas karena pemilik usaha memiliki kebun kayu sendiri yang ada di Desa Tombasian Atas. Sedangkan 5 responden lainnya menjawab karena tidak mempunyai kebun kayu sendiri pemilik membeli di desa tetangga atau di pengelolan kayu Desa Tareran. 
Sedangkan sumber bahan baku lainnya seperti batu teras berasal dari desa Tombasian Atas sendiri yang lokasinya tepat pada tempat pemajangan hasil-hasil industri rumah panggung. Dan untuk bahan baku seperti Seng, Paku, grendel pintu, engsel pintu, engsel jendela, kaca jendela, tarikan, baut, dan kunci dibeli di Toko Bangunan yang berasal dari desa tetangga di Kayuuwi dan di Toko Bangunan di Kawangkoan.

\section{Harga Bahan Baku}

Dari hasil wawancara selain 10 orang pemilik usaha rumah panggung memiliki hutan rakyat sendiri tetapi 5 diantaranya pemilik usaha rumah panggung membeli kayu langsung pada pengelola kayu di Desa Tareran dengan harga jual 7 $\mathrm{m}^{2}$ sebesar Rp.2.500.000. $13 \quad \mathrm{~m}^{2}$ sebesar Rp.3.750.000. $18 \mathrm{~m}^{2}$ sebesar Rp.5.000.000, harga yang digunakan sudah termasuk transportasi (terima di tempat). $7 \mathrm{~m}^{2}$ kayu bisa menghasilkan satu jenis rumah panggung dengan 1 kamar, $13 \mathrm{~m}^{2}$ kayu bisa menghasilkan satu jenis rumah panggung dengan 2 kamar, $18 \mathrm{~m}^{2}$ bisa menghasilkan satu jenis rumah panggung dengan 3 kamar.

Untuk harga bahan baku seperti paku 1 inch, 1,5 inch, 2 inch harga $1 \mathrm{~kg}$ dapat diperoleh seharga Rp. 22.000,- dan untuk ukuran 2,5 inch dan 4 inch seharga Rp. 18.000,-/kg. Harga baut yaitu Rp. 4.500,-, kemudian engsel pintu seharga Rp. 27.000,/buah, engsel jendela Rp. 21.000,-/buah, grendel jendela Rp. 10.000,-/buah, kaca jendela seharga Rp. 69.000,-/lembar, tarikan Rp. 10.000,- dan kunci Rp. $100.00,-/$ buah.

\section{Proses Pemesanan}

Pemesanan adalah proses pembelian yang dilakukan oleh konsumen kepada penjual sebelum konsumen mendapatkan barang. Kata order saat ini sangat sering digunakan untuk transaksi jual beli. Jika dulu kita mengenal dan sering mengatakan pesanan saat akan membeli barang, namun sekarang kita lebih mengenal namanya order. Kata order diartikan sebagai pesanan baik barang atau jasa yang dilakukan oleh pembeli kepada penjual.

Proses pemesanan pada industri Rumah Panggung di Tombasian Atas dari hasil penelitian 15 responden pemilik usaha rumah panggung mengatakan dimana sebagian besar pemesanan dilakukan setelah rumah panggung sudah selesai dibuat dan dipajang di lokasi industri rumah panggung, tetapi ada juga pemesanan dengan cara menggunakan lewat perantara dengan alat bantu media komunikasi atau telepon genggam (HP) dan memesan langsung kepada pemilik usaha sesuai kriteria rumah panggung yang diinginkan.

\section{Proses Penentuan Harga}

Dalam proses penentuan harga rumah panggung di Desa Tombasian Atas, pemilik usaha rumah panggung sudah menentukan harga per unit rumah panggung. Untuk harga per 1 unit rumah panggung dengan ukuran 1 kamar (6 x 5) sebesar Rp. 45.000.000, ukuran 2 kamar (7 x 9) sebesar Rp.75.000.000, ukuran 3 kamar (7 x 12) sebesar Rp.120.000.000. Harga yang telah dipatok oleh pemilik usaha adalah harga dimana konsumen menerima barang di tempat (terima kunci). Namun, harga dari rumah panggung yang ada masih bisa di negosiasikan konsumen dan pemilik, untuk mendapatkan keputusan bersama dalam penentuan harga.

Tabel 6. Ukuran rumah dan harga

\begin{tabular}{ccc}
\hline No & Ukuran Rumah & Harga \\
\hline 1 & 1 kamar $(6 \times 5)$ & $\mathrm{Rp}$ \\
& 45.000 .000$, \\
2 & 2 kamar $(7 \times 9)$ & $\mathrm{Rp}$ \\
& & 75.000 .000$, \\
3 & 3 kamar $(7 \times 12)$ & $\mathrm{Rp}$ \\
& & 120.000 .000$, \\
\hline
\end{tabular}

Sumber: Data Primer, diolah 2019.

\section{Pembuatan Desain}

Pembuatan desain dalam industri rumah panggung di Desa Tombasian Atas bervariasi, terdiri dari: Rumah tempat tinggal, Villa, Cottage, Tempat Kos, dan Perkantoran. Pembuatan desain ini tidak menggunakan arsitektur hanya menggunakan keahlian dari tukang rumah panggung. Tetapi tidak menutup kemungkinan juga untuk menggunakan arsitektur jika konsumen sudah memesan rumah panggung dan membuat sesuai keinginan sendiri.

Dari hasil penelitian yang dilakukan kepada 15 responden atau pemilik usaha rumah panggug semuanya menjawab design yang paling laris untuk industri rumah panggung yang ada di Desa Tombasian Atas, yaitu Rumah Panggung sebagai tempat tinggal karena industri rumah panggung yang ada di Tombasian Atas memiliki ciri khas yang tahan gempa dan nyaman untuk dijadikan tempat tinggal. Sementara, untuk desain lainnya seperti Villa, Cotage, Tempat Kos dan Perkantoran juga menjadi daya tarik tersendiri dari industri rumah panggung Tombasian Atas dan akandibuat ketika ada konsumen yang memesan. 
Ketika desain yang akan dibuat oleh pemilik industri rumah panggung yang belum dipesan oleh konsumen, tentunya pemilik akan menyesuaikan dengan bahan baku khususnya kayu yang tersedia dengan design yang akan dibuat. Agar tidak menyulitkan pemilik industri rumah panggung saat proses produksi.

\section{Proses Produksi}

Pada proses produksi yang terdapat dalam kegiatan produksi yaitu proses pengubahan baku menjadi bahan jadi melalui penggunaan tenaga kerja dan fasilitas produksi lainnya. Pembuatan rumah panggung merupakan bentuk kerajinan adat Minahasa dan dalam pembuatan rumah panggung kita harus menentukan tenaga kerja, ukuran rumah panggung, lama produksi, dan upah tenaga kerja. Jenis produk yang dihasilkan untuk memenuhi kebutuhan masyarakat dalam menentukan tempat tinggal.

\section{Persiapan}

Dalam industri rumah panggung di Desa Tombasian Atas pemilik usaha harus melakukan persiapan untuk pembuatan rumah panggung diantaranya persiapan bahan-bahan yang akan digunakan dalam pembuatan rumah panggung antara lain kayu, seng, danb paku. Dan juga harus mempersiapkan tukang yang akan membuat rumah panggung agar di dalam pembuatan rumah panggung berjalan dengan lancar.

\section{Pembuatan}

Proses produksi yang pertama yaitu pembuatan pondasi yang berasal dari campuran batu teras dan semen. Pondasi yang dibuat sebanyak tiang-tiang pada rumah panggung. Selanjutnya mulai dengan membersihkan kulit kayu atau proses menyerut kayu agar kayu terlihat bersih. Proses ini menggunakan mesin serut kayu agar hasilnya rapih, tetapi untuk melicinkan kayu menggunakan serut manual. Kemudian proses selanjutnya mulai dengan membat pola untuk dipahat, fungsinya untuk mengkaitkan tiang satu dan lainnya agar menjadi satu ikatan. Ini juga menjadi ciri khas industri rumah panggung yang ada di Desa Tombasian Atas, yang untuk mengkaitkan tiang tidak seutuhnya menggunakan paku, agar ketika gempa bumi rumah panggung tetap berdiri kokoh.

\section{Penyelesaian (Finishing)}

Finishing dalam proses industri rumah panggung di Desa Tombasian Atas yaitu dengan proses pemasangan lantai sementara tukang lainnya membuat lantai rumah, tukang yang lainnya membuat tangga untuk rumah. Setelah selesai lanjut dengan pemasangan dinding rumah dan pembuatan pintu dan jendela. Proses yang terakhir yaitu proses pemasangan atap rumah panggung.

\section{Pemasaran}

Berdasarkan penelitian dari 15 responden pemilik usaha rumah ranggung menyatakan untuk pemasaran industri rumah panggung yang ada di Desa Tombasian Atas Kecamatan Kawangkoan Barat memiliki beberapa bentuk pemasaran:

\section{a. Pemasaran Secara Langsung}

$$
\text { Pemasaran secara langsung }
$$
merupakan pemasaran yang dilakukan langsung oleh produsen ke konsumen seperti pemilik usaha rumah panggung menjual langsung produk yang ada kepada konsumen tanpa melalui perantara atau konsumen sendiri datang ke tempat produksi usaha rumah panggung yang berada di Jln. Raya Kawangkoan-Amurang untuk melihat sendiri unit rumah panggung.

\section{b. Pemasaran Secara Online}

Berkembangnya ilmu pengetahuan dan teknologi yang begitu pesat sehingga memudahkan semua usaha, baik itu usaha kecil, menengah, dan usaha besar dalam melakukan pemasaran melalui internet secara langsung. Dengan melihat perkembangan teknologi yang begitu pesat pemilik usaha membuat suatu pemasaran secara online dengan menggunakan buka lapak, facebook yang di dalamnya dicamtumkan tentang penjualan industri rumah panggung. Bentuk dan cara pemasaran secara online konsumen harus mencamtumkan barang yang di pesan dan memberi alamat yang lengkap serta nomor televon yang bisa di hubungi untuk proses berjalan dengan lancar. 


\section{Proses Distribusi}

Proses distribusi sangat di butuhkan oleh para konsumen agar dapat memperoleh barang-barang yang telah dihasilkan oleh produsen. Dari 15 responden pemilik usaha Rumah Panggung menyatakan bahwa saat ini penjualan industri rumah panggung di Desa Tombasian Atas sudah mencakup Sulawesi Utara, pulau Jawa, Papua, dan lain-lain. Untuk pengiriman barang usaha rumah panggung yang telah terjual pemilik sudah menentukan harga sejauh mana produk akan di bawahkan untuk pengiriman barang di Sulawesi utara pemilik sudah menyiapkan kendaraan yang akan dipakai dan sudah menentukan harga, tetapi konsumen juga bisa memakai kendaraan sendiri untuk proses pengiriman barang. Untuk distribusi di luar daerah atau antar pulau distribusinya menggunakan kapal laut dan biayanya ditanggung oleh pembeli/konsumen.

\section{Aktivitas dari Indistri Rumah Panggung}

Dari aktivitas industri rumah panggung yang ada di Tombasian Atas, terjadi dampak positif terhadap masyarakat setempat maupun pemerintah setempat. Dari dampak positif yang ada sehingga Industri rumah panggung di Desa Tombasian Atas sampai saat ini masih terus berjalan. Aktivitas industri bukan saja memberikan pendapatan bagi pemilik tetapi kepada pemerintah yang ada.

\section{Penye rapan Tenaga Kerja Dalam Industri Rumah Panggung}

Dari hasil penelitian, 15 responden pemilik usaha rumah panggung mengatakan tenaga kerja dalam industri kerajinan rumah panggung di Desa Tombasian Atas keseluruhan berjenis kelamin laki-laki. Dalam industri kerajinan rumah panggung sebagian pengerajin ikut terjun langsung dalam industri kerajinan itu sendiri. Dari hasil penelitian menunjukkan bahwa semua pekerja berasal dari Desa Tombasian Atas sendiri. Sehingga tenaga kerja dalam industri rumah panggung memanfaatkan sumber daya manusia yang terdapat di dalam Desa tersebut.
Tabel 6. Ukuran rumah, Jumlah Tenaga Kerja dan lama produksi

\begin{tabular}{|c|c|c|c|}
\hline No & $\begin{array}{l}\text { Ukuran } \\
\text { Rumah }\end{array}$ & $\begin{array}{c}\text { Jumlah } \\
\text { Tenaga Kerja }\end{array}$ & $\begin{array}{c}\text { Lama } \\
\text { Produksi }\end{array}$ \\
\hline 1 & $\begin{array}{c}1 \text { kamar }(6 x \\
5)\end{array}$ & 3 orang & 1 bulan \\
\hline 2 & $\begin{array}{c}2 \operatorname{kamar}(7 \mathrm{x} \\
9)\end{array}$ & 4 orang & 2 bulan \\
\hline 3 & $\begin{array}{c}3 \text { kamar }(7 x \\
12)\end{array}$ & 5 orang & 3 bulan \\
\hline
\end{tabular}

Tabel 6 menunjukkan bahwa dalam pembuatan industri rumah panggung, untuk pembuatan ukuran rumah 1 kamar $(6$ x 5$)$ jumlah tenaga kerja 3 orang lama produksi 1 bulan, pembuatan ukuran rumah 2 kamar $(7 \mathrm{x}$ 9) jumlah tenaga kerja 4 orang lama produksi 2 bulan, dan pembuatan ukuran rumah 3 kamar $(7 \times 12)$ jumlah tenaga kerja 5 orang lama produksi 3 bulan.

\section{Upah Tenaga Kerja}

\section{Upah Harian}

Dijelaskan menurut waktu, setiap tenaga kerja dibayar dalam satuan waktu misalnya sekian rupiah per bulan atau per hari. Misalnya pembayaran dihitung perhari kerja 1 hari dihitung kepala bass Rp 175.000, kenek Rp 125.000, dan cara pembayaran dilakukan per mingu dihitung berapa hari kerja dalam satu minggu dan dibayar pada hari kerja terakhir pada minggu yang berjalan.

\section{Upah Borongan}

Upah borongan ialah upah yang di bayarkan berdasarkan suatu unit pekerjaan secarah keseluruhan. Pekerjaan yang menggunakan sistem upah borongan adalah usaha industri rumah panggung. Untuk pembayaran misalnya tukang atau pekerja sudah menentukan harga borongan per unit rumah panggung yang akan di buat. Harga borongan per 1 unit rumah panggung 1 kamar sebesar Rp. 10.000.000, 2 kamar sebesar Rp. 18.000.000, dan 3 kamar sebesar Rp.22.000.000. 


\section{Pendapatan Industri Rumah Panggung}

\section{Pendapatan Bagi pemilik}

Adanya industri rumah panggung memberikan keuntungan bagi pemilik yang memiliki usaha rumah panggung karena usaha rumah panggung yang ada di Desa Tombasian atas masih milik sendiri atau pribadi. Usaha rumah panggung sangat juga menguntungkan pemilik, dikarenakan ada pemilik usaha juga sebagai tukang. Selain itu rumah panggung juga membuka lapangan pekerjaan bagi masyarakat yang tidak bekerja ataupun juga banyak yang beralih pekerjaan dari pekerjaan petani beralih ke pekerjaan tukang. Perkembangan industri rumah panggung ini memberikan motivasi yang sangat besar bagi masyarakat untuk tetap mengelola dan mengembangkan industri ini karena saat ini industri rumah panggung merupakan salah sumber pendapatan yang sangat menguntungkan bagi perekonomian masyarakat/keluarga.

\section{Pendapatan Bagi Desa}

Perkembangan industri rumah panggung memberikan dampak positif terhadap keuntungan yang diperoleh Desa Tombasian Atas, karena didalam pembangunan industri rumah panggung keuntungan yang didapat dimana jika suatu usaha rumah panggung terjual maka akan memberikan pajak per unit untuk desa dimana 1 unit rumah panggung dikenakan pajak sebesar Rp.75.000. 2 unit rumah panggung sebesar Rp.100.000. 3 unit rumah panggung sebesar Rp.150.000, pajak yang diperoleh akan dikelola untuk pembangunan desa kedepan.

\section{Pendapatan Bagi Masyarakat didaerah Industri}

Keuntungan bagi masyarakat diartikan bahwa didalam penjualan rumah panggung pasti ada proses distribusi. Proses distribusi ini menggunakan transportasi atau kendaraan dimana masyarakat yang memilki kendaraan roda empat/mobil pickup mendapat keuntungan jika didalam penjualan unit rumah panggung pemilik tidak mempunyai kendaraan maka pemilik akan mencari atau menyewa kendaraan untuk proses ditribusi.

\section{KESIMPULAN DAN SARAN}

\section{Kesimpulan}

Berdasarkan hasil penelitian, aktivitas dari industri rumah panggung di Desa Tombasian Atas meliputi aktivitas produksi dimana persiapan bahan baku dari mana asal bahan baku jenis apa bahan baku yang digunakan. Proses desain ditentuknan oleh pemilik namun juga bisa ditentukan oleh konsumen untuk cara pemesanannya secara langsung atau di pajang di tempat pembuatan maupun pemesanan secara online (media sosial), distribusi sudah sampai dalam daerah dan luar daerah Sulawesi Utara. Pemasaran pada umumnya di pajang langsung dan di promosikan di media soial. Aktivitas dari industri rumah panggung memberikan pendapatan dimana terjadi penyerapan tenaga kerja dari dalam desa sendiri. Untuk pembuatan rumah panggung ukuran 1 kamar (6 x 5) menyerap 3 tenaga kerja, 2 kamar $(7 \mathrm{x}$ 9) menyerap 4 tenaga kerja, 3 kamar $(7 \times 12)$ menyerap 5 tenaga kerja. Upah yang diberikan upah harian kepala bas Rp. 175.000, kenek Rp. 125.000, dan upah borongan 1 kamar Rp. 10.000.000, 2 kamar Rp. 18.000.000, 3 kamar Rp. 22.000.000,. Pendapatan bagi pemilik 1 kamar (6 x 5) Rp. 45.000.000, 2 kamar (7 x 9) Rp. 75.000.000, 3 kamar (7 x 12) Rp. 120.000.000,. Pendapatan bagi desa dikenakan pajak setiap rumsh panggung terjual 1 unit Rp. 75.000, 2 unit Rp. 100.0003 unit Rp. 150.000., Pendapatan bagi masyarakat daerah sekitar menyewa kendaraan untuk proses ditribusi Rp. 600.000, sampai Rp. 1.200.000, tergantung jarak tempuh.

\section{Saran}

Bagi pemilik usaha rumah panggung di Desa Tombasian Atas, agar terjadi peningkatan aktivitas produksi rumah panggung maka proses promosi/pemasaran melalui media online harus ditingkatkan misalnya dengan membuat website usaha rumah panggung serta terus menjaga kualitas dan ketersediaan bahan baku rumah panggung agar aktivitas produksi terus berjalan. 


\section{DAFTAR PUSTAKA}

Alam, S. 2006. Ekonomi Jilid 1. Esis. Semarang.

Nababan. C. D. 2009. Analisis Faktor-Faktor Yang Mempengaruhi Pendapatan Petani Jagung Di Kecamatan Tiga Binanga Kabupaten Karo.Skripsi. Universitas Sumatra Utara.
Pelle C.M. 2012. Potensi Tabungan Rumah Tangga Petani Di Desa Poopo Utara Kecamatan Ranoyapo. Skripsi. Fakultas Pertanian Universitas Sam Ratulangi Manado.

Tjokroamidjojo. $1995 . \quad$ Pengantar Administrasi Pembangunan. LP3S. Jakarta. 